\title{
MENTAL MAP OF THE CITY: ELEMENTS OF VISUAL ARGUMENTATION AND CREATIVITY IN MODERN CITY PLANNING
}

\author{
Borbála JÁSZ* \\ Budapest University of Technology and Economics, Faculty of Economic and Social Sciences, \\ Institute of Social Sciences, Department of Philosophy and History of Science
}

Received 15 June 2017; accepted 03 November 2018

\begin{abstract}
Lewis Mumford in The City in History (first edition in 1961) emphasises that the structure of modern cities is partially responsible for many social problems seen in Western society. Urban planning should concentrate on an organic relationship between people and their living spaces. The city is a product of Earth, a fact of nature, man's method of expression, Mumford writes in his The Culture of Cities (first edition in 1938). This also means that both the designer and the user must have a high degree of creativity in order to design and utilise the built environment. By analysing the definition of the city Mumford examines its changes during history from ancient times to recent planning method. He criticises the most dominant design processes of the 20th century: the functionalist and mechanical urban design. He is an advocate of the organic method in planning and understanding cities. The organic approach requires an active and creative approach as opposed to mere passive reception.

This organic approach by Mumford to understanding cities is based on the theory of Kevin A. Lynch. We may distinguish 3 normative ways of city planning theory: (1) the cosmic, (2) the mechanic and (3) the organic model.

In my paper I will first apply the onion model of culture developed by Geert Hofstede for the city and its analysis, and also for the appearance of creativity in them. After that I am going to examine the city with a special, architectural based mind map theory: the five elements by Lynch. Lynch suggests that these five elements (paths, edges, districts, nodes, landmarks) create the mental map for readability. Finally, I will investigate a usage of mental map in modern city planning (Le Corbusier) and works on the process of "debabelisation" (Otto Neurath).
\end{abstract}

Keywords: city planning, creativity, Hofstede, Lynch, mental map, urban design, visual argumentation.

\section{Introduction}

An ancient Egyptian hieroglyph shows the word "city" by an illustration: a circle and a cross. This symbol means an interrelation between protection and central location. The city as the

${ }^{\star}$ Corresponding author. E-mail: jasz.borbala@filozofia.bme.hu 
centre of civilisation has undergone many changes. This is discernible after the industrial revolution, which was the most dominant reason for the urbanisation.

If we would like to analyse the visual aspect of a city, we are going to find that nowadays many layers from different ages exist together. We explore the city where we are inhabitants in a very different manner from the city where we are tourists only. We will be disorientated when we are displaced from our own cultural terrain. For example, when the streets are numbered instead of being named, when we encounter left-hand traffic instead of right-hand traffic, etc. This entails that in differently planned cities people have to orientate themselves differently. It can be assumed that a city has several layers of meaning and these are closely related to the common cultural values. Hofstede worked out a hierarchy of cultural layers and I suggest that the application of these layers to the built heritage will be fruitful for a deeper understanding of our built environment (1980, p. 34).

The onion model of culture was created by Hofstede in 1991, in which culture and communication are inseparable. The core consists of values and the dimensions that make up a culture as follows: rituals, heroes, symbols. The core of values and the three dimensions are closely related to the built heritage and using method of buildings and urban spaces due to the five elements of Lynch.

Hofstede's onion model presents three layers around a core. The core stands for the values of a certain culture, and their change is always slow, they mostly remain constant. Even if something seems to be outdated today, it may still play a role subconsciously for a long period of time, for individuals and groups as well.

The first layer around the core is described as rituals which are changing slowly. The second layer around the core is the hero. A hero can be a fictive person who has influence on the culture, but heroes may also be national heroes (e.g. scientists), and the like: heroes are real of fictive persons who play a role-model in a given society. The third layer is about the symbols which usually change with current trends. All three layers may be taught and learned through practical knowledge except for the core: the inner cultural values (e.g. good versus bad, dirty versus clean, ugly versus beautiful, unnatural versus natural, irrational versus rational).

To apply the onion model of culture for the built environment, we have to ask three questions: What can a building communicate? How can a building communicate? How can a city communicate? To answer these questions, the three normative ways of city planning will be marked: the cosmic, the mechanic and the organic way. A lot of people live in mechanic planned cities nowadays, and it is extremely interesting to make a mental map in a standardised and typified city, thus I will focus on the mental mapping in these kinds of cities.

\section{What and how can a building communicate?}

To make this question clear the Bilbao effect should be mentioned. This effect can be analysed from the aspect of economics and cultural industry. In Bilbao a starchitect ${ }^{1}$ designed a prestige building due to a huge financial growth and prestige. The aim of this was to create a

\footnotetext{
${ }^{1}$ Starchitect is a portmanteau that is used to describe an idolised top architect.
} 
landmark (which is one the five elements by Lynch) for the city. ${ }^{2}$ The new museum building by Frank Gehry placed Bilbao on the cultural map of the world. The building communicates architectural extravaganza, bravery, ground-breakingness, and consequently richness, success and celebrity. In this case creativity can be found in the designer's conceptualisation:

$"<\ldots>$ the building continues to attract visitors even though the collection on display is modest. Other cities without historic cultural centres now look to Bilbao as a model for what vision and imagination can achieve" (The Economist, 2014).

Another example is that buildings are often used on the logo of universities. Considering that often classical buildings are shown on the logo, we may realise what a building can communicate in these cases: tradition, representativity, beauty, durability, utility, quality, functionality, and brand. How can it communicate these to the viewer? The architect has to use the same architectural principles at the building as the brand designer at the logo: symmetry, traditionalism, appearance in applied arts. In the modern formulation of classic content creativity plays a central role.

In case of the central building of the Budapest University of Technology and Economics we may find a multi-level communication. The neo-renaissance building is located on the representative riverside of the Danube. Its function has been maintained since the turn of the 19th and 20th century. From the urban aspect the street in front of the building is named after the University. The logo of the university is based on the portrayal of the central building, which is a pronounced element of the image.

This case study demonstrates that a building may express and reflect common values according to Hofstede's model. It is necessary to examine single buildings from this approach, because these houses are the building blocks of cities: as a single building may mediate a meaning due to its visual communicative means, in case of cities the same process may be observed on a different (city wide) scale.

\section{How can a city communicate?}

Lynch was an American architect and urban planner, and he worked with the famous organic designer Frank Lloyd Wright. He was a professor at Massachusetts Institute of Technology (MIT) and influenced generations of students. His mission was to plan our environment, and to this effect he wrote several theoretical works on this topic. One of the most significant of these is The Image of the City (Lynch, 1960), in which he emphasised the empirically based analysis of the built environment - including its inhabitants. The book focuses on the visual experiences and corresponding associations and memories. Lynch introduced the concept of mental mapping, a special case of mind mapping in planning and analysing cities.

At the beginning of his book Lynch emphasises the importance of historical attitude both in planning and analysing cities:

\footnotetext{
2 Similar examples are the Imperial War Museum North (2002) in Manchester, England, United Kingdom by Daniel Libeskind, the Museum of Contemporary Art Kiasma in Helsinki, Finland (1998) by Steven Holl, and the Seattle Central Library (2004) in Washington, United States by OMA.
} 
"Looking at cities can give a special pleasure, however commonplace the sight may be. Like a piece of architecture, the city is a construction in space, but one of vast scale, a thing perceived only in the course of long spans of time. City design is therefore a temporal art $\langle\ldots\rangle$. At every instant, there is more than the eye can see, more than the ear can hear, a setting or a view waiting to be explored. Nothing is experienced by itself, but always in relation to its surrounding, the sequences of events leading up to it, the memory of past experiences" (1960, p. 1).

The goal of city planning is the ordering of the city. Modern city planners have adopted a particular paradigm of order. Synoptic planning method replaced traditional views of order with a new world-view. In a scientific understanding of natural ordering processes in the theory of Lynch (1981, p. 72) we can distinguish three normative models of city planning:

(1) The first one is the cosmic planning which means that the texture of cities is based on some metaphysical attributing, e.g. baroque cities. This is connected to the theory of ideal cities. The ideal nature of a city encompasses the moral, spiritual and juridical qualities of citizenship. These are realised through urban structures including buildings and street layouts. The ground plans of ideal cities are often based on grids or other geometrical patterns. The ideal city is often an attempt to deploy utopian ideals;

(2) In the machine age the mechanic planning dominates. After both World Wars a dominant aim was to build cheap flats quickly. This lead to the construction of residential cells and blocks of houses (Siedlungs). In this model the function of the city is analogous to the work of the human body. This may be observed in the plans of Le Corbusier, e.g. Chandigarh and the concept of the radiant city (Le Corbusier, 1967). The streets and traffic are analogous to the circulation of the blood, the centre of the city to the heart, parks and other green areas to the lungs, etc. Here we can find the effect of Cartesian philosophy, especially the machinebody (res extensa) by René Descartes, which means the mechanised concept of the human body. In this case it is the combination of anthropomorphic and mechanical approaches. Charalampos Politakis argues that the famous Le Corbusierian statement, "the house is a machine for living" (Le Corbusier, 2007, p. 151), is based on this Cartesian machine-body concept and it portrays the human body as a building (Politakis, 2018, p. 5);

(3) The third model by Lynch is the organic one, which is as important as it is in Mumford's theory. In both design theories the same argument is made about the importance of humanbased organic planning (Diefendorf, 1993, pp. 188-190). Mumford emphasised in his The City in History that the structure of modern cities is partially responsible for many social problems seen in Western society (1961). Urban planning should emphasise an organic relationship between people and their living spaces. He defines city as "a product of Earth, a fact of nature, man's method of expression" (Mumford, 1970, pp. 3-4). He considers the Roman city to be the ideal.

In the following part of my paper I will demonstrate these three types of urban design with emblematic examples from the 20th century.

\section{Case study for cosmic planning: the international world city}

When a designer would like to create a new city and make it liveable, applying Hofstede's onion model would be artificial. This is a kind of utopian, cosmic planning method, which neglects creativity. The best example is the Mundaneum project to create the international 
world city. The framework was laid down by the League of Nations (LN) in the interwar period.

The LN was founded after World War I. This was the first organization to pursue and maintain world peace. In 1926 an international competition was announced for the design of its buildings in Switzerland. First it was won by Le Corbusier, but later his submission was excluded for formal reasons. The conflict began to unfold with this project, which further evolved with the design of the Cité Mondiale. The basic idea of the Mundaneum originates from Paul Otlet, a Belgian documentalist and utopistic internationalist. It was the task of the architect to implement this ideology into architecture (Teige, 1929).

The project was to be located on an international site overlooking Lake Geneva, at the foot of the Jura Mountains. The features of cosmopolitanism and internationalism prevailing already in the genius loci, were preferred to the regional and personal attitude in order to create an international city. All this was the great task of post-war peace, which, together with the Palace of Nations, was meant to become the centre of the modern world. It is supported by five functions, which, as the institutions of intellectual creativity, were included in the design: library, space for the scientific communities, university, museum and institutions. This complex is a unified centre of sciences, philosophical and artistic associations, social and artistic movements, and it also houses an educational and hygienic centre and an archive. The focal point of Otlet's idea was universal interdependence, and unified culture and civilization crossing borderlines and uniting 2 billion people. In his idea, he incorporated biological and physical aspects which embody the international economic, political and social life. The objective was to keep peace and the international union. Otlet regarded the Panathenaea, the library in Alexandria, the ancient Chinese encyclopaedia, medieval monasteries, abbeys and cathedrals, universities, royal palaces, Palace of Versailles, the French and Russian scientific academies and the Port Royale as his ideological forerunners. This building complex was meant to become the institution of intellectual life and culture (Teige, 1929).

This Mundaneum project is the latest example for cosmic planning, where instead of the human needs, including creativity, the application of rules from geometry, morality, religion, history, etc. gains preference. During the 20th century human needs became more important, thus this project could not be realised; it remained a utopia only.

\section{Case study of the mechanic planned functional city}

To understand the modern, mechanic metropolis a deductive approach may be used. This analysis starts with people's orientation in a mechanic planned city. These kinds of cities have a standardised, regular structure; it is hard to find our ways around in these cities by looking at the buildings only. In the interwar period several designers started to work out a universal picture language to solve this problem.

The universal, visual language system (called Isotype (picture language)) was created by Neurath between the two World Wars. The main question was why and how we can understand visual elements. Neurath and Le Corbusier followed the "unity of science" idea of the Vienna Circle in educating the masses and in city planning. Both of them worked on 
the metropolis, so a methodological analogy can be seen between a language of visual elements and the city. Le Corbusier emphasised the readability of cities, where "city" means the global polis. Neurath created his Isotype (picture language) for Le Corbusian-type modern metropolises $(1980$, p. 22). In order to examine the actuality of the pictograms, they have to be analysed in terms of the work of György Kepes and Lynch. Lynch's theory was developed under the direction of professor Kepes at the Center for Urban and Regional Studies of the MIT in 1959. Kepes was a Hungarian-born artist, painter, designer and theorist. After immigrating to the United States, he taught at the New Bauhaus in Chicago and later at MIT. The Language of Vision is Kepes' best known work on design education:

"The language of vision, optical communication, is one of the strongest potential means both to reunite man and his knowledge and to re-form man into an integrated being $\langle\ldots\rangle$. Visual communication is universal and international; it knows no limits of tongue, vocabulary, or grammar, and it can be perceived by the illiterate as well as by the literate $\langle\ldots\rangle$. (The visual arts as) the optimum forms of the language of vision, are, therefore, an invaluable educational medium" (1944, p. 13).

In addition to the city structure Lynch focused on the city's mental representation, which requires creativity from the users, as well. This is based on the concept of imageability (Lynch, 1960, pp. 9-13). But how could his programme be applied to the elements of the city? Lynch distinguished five different elements of the city: paths, edges, nodes, landmarks and districts. Every major settlement is built up from these components, thus we can read them. So legibility and transparency are crucial to an understanding of cities. To understand the city, the activities of inhabitants must be observed. "Structuring and identifying the environment is a vital ability among all mobile animals" (Lynch, 1960, p. 3).

The theories of Neurath and Le Corbusier with regard to visualisation are connected in three ways. First of all, with respect to the common task: to make scientific results accessible for the masses. Secondly, with respect to the intermediary device: the mass media are very powerful. Thirdly, the aim of Neurath and Le Corbusier was the same: understanding the modern metropolis. These three links result in three core notions which are the hallmarks of the Modern Movement in Central and Western Europe: globalism, knowledge, and everyday life. In order to understand the closely related social and architectural trends between the two World Wars, we need to focus on these three concepts (which later became tendencies).

In modern cities (classical modern and newly built cities) people cannot get lost, because they are supported by navigation devices which are visual: maps, numbers of public transport vehicles, route signs, markers for buses or trams, etc. The most important requirement for the problem of the image of the city is transparency. So we need objective, clearly visible signs (debabelisation), not just to use them but to understand the city. These signs must be understandable for everyone thus they must be visual. Hofsteede - in his book entitled Exploring Culture - emphasises the importance of the visuality in cities. The authors work with the notion of city from the theoretical and practical approach as well. "There are many degrees of freedom in designing a city, because a city can hold buildings or infrastructure for just about all the social activities that people can engage in" (G. J. Hofstede, Pedersen, \& G. Hofstede, 2002, p. 228). 


\section{C. Rowe about Rome's organic planning}

Collin Rowe, who was a Professor at Cornell University, examined the texture of the city from the 1960s. With his university students, they studied Giambattista Nolli's plan for Rome from 1784 regarding the fullness and emptiness of urban space. Nolli's plan represented the traditional urban space, which was determined by continuity. Modern cities scrapped this traditional texture and the body of buildings were positioned into an empty space. This may be called the tabula rasa of architecture. Cities lost their special architectural qualities and human scale, and the publicity of cities was broken.

Nolli made a lot of important innovations. Firstly, Nolli re-orients the city from East (which was conventional at the time) to magnetic North, reflecting Nolli's reliance on the compass to get a bearing on the city's topography. Secondly, Nolli represents enclosed public spaces such as the colonnades in St. Peter's Square and the Pantheon, Rome as open civic spaces. Finally, the map was a significant improvement in accuracy, even noting the asymmetry of the Spanish Steps. The map was used in government planning for the city of Rome until the 1970s; it was used as a base map for all Roman mapping and planning up to that date (Rowe \& Koetter, 1978, pp. 77-80).

A city cannot be planned to be a unit, because various efforts prevail in it. In city planning the monolithic, political will or scientific rationality does not work; the best way is the method of bricolage (Rowe \& Koetter, 1978, pp. 77-80). It unites various kinds of knowledge and creative abilities. Rowe is against the utopian and ideological architecture theory of Le Corbusier. In this case the onion model was tacitly applied during the design process. This city is called organic, because it was constituted in history. In so-called classical cities the same bricolage method was utilised, e.g. in Budapest, the Hungarian capital.

The common cultural value in case of the old town of Budapest is that this is an EastCentral European capital, the structure of which is constituted by history in the 19th century. This can be seen in the structure of the city, which is based on the city planning method of Georges-Eugène Hausmann's Paris. The city is organised by huge allees, avenues and two rings, what can be also observed in case of Vienna, Austria, Prague, Czech Republic, etc. The readability of their structure is common in these cities. The rituals are connected to the values, which are constituted by using the city: transport habits, city public institutions, education, religion and entertainment. There are special building types for these functions. This layer is accessible for everyone in the city.

We need a deeper understanding to decode the heroes in this urban situation. We may find them in the name of streets and for example in the sculptures on the squares. This is closely related to the symbols, which are hidden to the tourists; these are understandable only for inhabitants. In case of Budapest a symbolic number is 96 . This refers to the foundation of the Hungarian state in 896. The Parliament was built in 1896 in a difficult political situation, when it expressed the national consciousness. The height of the cupola of the Parliament building is 96 meters and the basilica's cupola, which is named after the founder of the state Saint Stephen (Szent István), is 96 meters tall as well. The situation is similar in many cities, for example the role of number 7 in Bratislava.

According to Hofstede's model the analysis of Budapest (and most of European historical cities) shows different shells. The cultural values and rituals may be accessible for everybody. 
People can get to know the city at these levels as tourists or by maps. In order to know heroes and symbols in the city people need special knowledge. These aspects are important both in planning and analysing these classical cities; all of four elements by Hofstede are discoverable.

\section{Conclusions}

This paper applies Hofstede's onion model of culture for the city and its analysis. The core of the model consists of values and the dimensions that make up a culture are as follows: rituals, heroes, symbols. These notions of Hofstede may be applied for investigating what and how a building can communicate. My case study demonstrates that a building can express and reflect common values according to Hofstede's model. As a single building may mediate meaning due to its visual communication means, in case of cities the same process may be observed on a different scale.

Lynch emphasised the empirically based analysis of the built environment - including its inhabitants in his Image of the City. He worked out a mental mapping method of five elements to understand cities. According to Mumford, Lynch distinguished three types of cities. This essay contains examples for all three types: the cosmic, the mechanic and the organic way. Creativity is an important aspect of the organic approach.

Applying Hofstede's onion model for the cosmic, utopian planning would be artificial. An example for this was the Mundaneum project from the interwar period. In case of mechanical cities some aid is needed, because unification terminates the levels of understanding. The role of pictures in the environment of a metropolis is mediative. A universal picture language makes connections between inhabitants in the new kind of cities and between words and built entities.

In case of traditional cities, which were constructed during history, over a longer period of time, sections of the city continually reveal themselves. Over time understanding of the city deepens, and Hofstede's onion-model is applicable. This is confirmed by the case study of the bricolage approach (which contains various kinds of knowledge and creative abilities) of the city written by Rowe.

\section{Note}

This paper was supported by the Hungarian-Lithuanian joint project Conception of Creative City within Central Europe: Historical Images and Empirical Indices carried on within the framework of a bilateral agreement of the Hungarian and Lithuanian Academies of Sciences.

\section{References}

Diefendorf, J. M. (1993). In the wake of war: the reconstruction of German cities after World War II. New York, Oxford: Oxford University Press.

Hofstede, G. (1980). Culture's consequences: international differences in work-related values. Series: Cross-Cultural Research and Methodology Series. Vol. 5. Newbury Park, London, New Delhi: SAGE Publications. 
Hofstede, G. J., Pedersen, P. B., \& Hofstede, G. (2002). Exploring culture: exercises, stories and synthetic cultures. London: Nicholas Brealey Publishing.

Kepes, G. (1944). The language of vision: painting, photography, advertising-design. Chicago: Paul Theobald and Company.

Le Corbusier. (1967). The radiant city: elements of a doctrine of urbanism to be used as the basis of our machine-age civilization. New York: Orion Press.

Le Corbusier. (2007). Toward an architecture. Series: Texts and Documents. Los Angeles: Getty Research Institute.

Lynch, K. (1981). Good city form. Massachusetts: Massachusetts Institute of Technology.

Lynch, K. (1960). The image of the city. Massachusetts, Cambridge: The M.I.T. Press.

Mumford, L. (1961). The city in history: its origins, its transformations, and its prospects. San Diego, New York, London: Harcourt, Inc.

Mumford, L. (1970). The culture of cities. San Diego, New York, London: Harcourt Brace Jovanovich, Publishers.

Neurath, O. (1980). International picture language. Reading: University of Reading.

Politakis, Ch. (2018). Architectural Colossi and the human body: buildings and metaphors. Series: Routledge Research in Architecture. London and New York: Routledge.

Rowe, C., \& Koetter, F. (1978). Collage city. Cambridge, Massachusetts, London: The MIT Press.

Teige, K. (1929). Mundaneum. In Stavba 7: 145.

The Economist. (2014). The Bilbao-effect: if you build it, will they come? Retrieved from https://www. economist.com/special-report/2014/01/06/the-bilbao-effect

\title{
MIESTO MENTALINIS ŽEMĖLAPIS: VIZUALINIO ARGUMENTAVIMO ELEMENTAI IR KÜRYBIŠKUMAS ŠIUOLAIKINIO MIESTO PLANAVIMO PROCESE
}

\author{
Borbála JÁSZ
}

\begin{abstract}
Santrauka
Lewisas Mumfordas Mieste istorijoje (pirmasis leidimas - 1961 m.) pabrèžia, kad šiuolaikinių miestų struktūrai tenka dalis atsakomybès dèl daugelio socialinių problemų, regimų Vakarų visuomenejje. Miesto planavimas turètų būti koncentruojamas ị organišką ryši tarp žmonių ir jų gyvenamųjų erdvių. Miestų kultūroje (pirmasis leidimas - 1938) Mumfordas rašo, kad miestas - tai Žemès produktas, gamtos ịvykis, žmogiškosios išraiškos metodas. Tai taip pat reiškia, kad tiek projektuotojas, tiek vartotojas turi būti itin kūrybiškas, idant suprojektuotų ir panaudotų sukurtą aplinką. Analizuodamas miesto apibrèžimą, Mumfordas nagrinėja jo kaitą istorijoje nuo antikos laikų iki dabartinio planavimo metodo. Jis kritikuoja XX a. labiausiai ísivyravusius projektavimo procesus: funkcionalistinị ir mechaninị miesto projektavimą. Jis yra organinio metodo, taikomo miestams planuoti ir suprasti, šalininkas. Organiškas požiūris reikalauja aktyvaus ir kūrybiško požiūrio, priešpriešinamo grynai pasyviam suvokimui.

Šis organiškas Mumfordo požiūris, suprantant miestus, grindžiamas Kevino A. Lyncho teorija. Galime išskirti tris normatyvinius miesto planavimo teorijos būdus: 1) kosminị; 2) mechaninị; 3) organinị modelị.
\end{abstract}


Straipsnyje pirmiausia taikomas svogūninis kultūros modelis, kurị miestui ir jo analizei, taip pat jų kūrybiškumo pasireiškimui sukūrẻ Geertas Hofstede. Paskui nagrinejjamas miestas, pasitelkiant ypatingą, architektūra grindžiamą proto žemèlapio teoriją - penkis Lyncho elementus. Lynchas teigia, kad šie penki elementai (takai, pakraščiai, rajonai, susikirtimo taškai, peizažai) kuria mentalinị reglamentavimo žemèlapi. Galiausiai tyrinejjama, kaip proto žemèlapis naudojamas šiuolaikiniam miestui planuoti (Le Corbusier) ir kokią ịtaką daro „debabilizacijos“ procesui (Otto Neurathas).

Reikšminiai žodžiai: miesto planavimas, kūrybiškumas, Hofstede, Lynchas, mentalinis žemèlapis, miesto projektavimas, vizualinis argumentavimas. 